\title{
Vapor plumes in a tropical wet forest: spotting the invisible evaporation
}

\author{
César Dionisio Jiménez-Rodríguez ${ }^{1,2}$, Miriam Coenders-Gerrits ${ }^{1}$, Bart Schilperoort $^{1}$, \\ Adriana del Pilar González-Angarita ${ }^{3}$, and Hubert Savenije ${ }^{1}$ \\ ${ }^{1}$ Water Resources Section, Delft University of Technology, Stevinweg 1, 2628 CN Delft, the Netherlands \\ ${ }^{2}$ Tecnológico de Costa Rica, Escuela de Ingeniería Forestal, 159-7050, Cartago, Costa Rica \\ 3 independent researcher
}

Correspondence: César Dionisio Jiménez-Rodríguez (cdjimenezcr@gmail.com)

Received: 13 January 2020 - Discussion started: 23 January 2020

Revised: 19 December 2020 - Accepted: 22 December 2020 - Published: 11 February 2021

\begin{abstract}
Forest evaporation exports a vast amount of water vapor from land ecosystems into the atmosphere. Meanwhile, evaporation during rain events is neglected or considered of minor importance in dense ecosystems. Air convection moves the water vapor upwards leading to the formation of large invisible vapor plumes, while the identification of visible vapor plumes has not yet been studied. This work describes the formation process of vapor plumes in a tropical wet forest as evidence of evaporation processes happening during rain events. In the dry season of 2018 at $\mathrm{La}$ Selva Biological Station (LSBS) in Costa Rica it was possible to spot visible vapor plumes within the forest canopy. The combination of time-lapse videos at the canopy top with conventional meteorological measurements along the canopy profile allowed us to identify the driver conditions required for this process to happen. This phenomenon happened only during rain events. Visible vapor plumes during the daytime occurred when the following three conditions are accomplished: presence of precipitation $(P)$, air convection, and a lifting condensation level value smaller than $100 \mathrm{~m}$ at $43 \mathrm{~m}$ height (zlcl.43).
\end{abstract}

\section{Introduction}

Forest cover in tropical regions is endangered by deforestation (Curtis et al., 2018; Rosa et al., 2016), compromising the evaporation flux from land. Forest evaporation is a mixture of water vapor originating from water intercepted on plant surfaces, soil water, and plant transpiration (Roberts, 1999;
Savenije, 2004; Shuttleworth, 1993). Forest evaporation is considered of major importance as a regional and local cooling system (Ellison et al., 2017) as a result of its capacity to recycle the atmospheric moisture at different timescales (van der Ent and Savenije, 2011). The water vapor originating from evaporation at the surface is horizontally transported in the atmosphere by advection (Lavers et al., 2015; Strong et al., 2007), where forest presence at continental scale induces the "biotic pump mechanism" that favors the maintenance of similar precipitation amounts between inland and coastal environments (Makarieva and Gorshkov, 2007; Makarieva et al., 2013a). Meanwhile, vertical transport is linked to wind shear (Chen et al., 2015) and convection (Trzeciak et al., 2017) that, in large ecosystems, influence the formation of convective clouds at the top of the atmospheric boundary layer (Fuentes et al., 2016; Manoli et al., 2016). This process plays an important role in the formation of precipitation in tropical basins (Adams et al., 2011; van der Ent and Savenije, 2011) because of the contribution of water vapor originating from local evaporation (Brubaker et al., 1993).

Evaporation is usually neglected or considered of minor importance during rain events in dense forest ecosystems (Klaassen et al., 1998). This is because during rainfall the vapor pressure deficit is close to zero (Bosveld and Bouten, 2003; Loescher et al., 2005; Mallick et al., 2016), reducing the atmospheric water demand and stopping the transpiration process (Gotsch et al., 2014). However, the increment of evaporation with the size of rain events suggests that evaporation also occurs during the events and not only after- 
wards (Allen et al., 2020). This has been evidenced by discrepancies found between modeled and measured evaporation rates in tropical forests (Schellekens et al., 2000). When it rains, part of the precipitation is intercepted and evaporated directly to the atmosphere (David et al., 2006) even when vapor pressure deficit and available radiation are low (Lankreijer et al., 1999). Under high-humidity conditions, a portion of the precipitation can evaporate after a raindrop splashes on the canopy or the forest floor. This process is known as "splash-droplet evaporation" (Dunin et al., 1988; Dunkerley, 2009; Murakami, 2006) and is based on the principle that raindrop size increases with rain intensity. Consequently, when larger drops hit the surface (e.g., ground, leaves, and branches), this allows the formation of smaller rain droplets that can be easily evaporated after the splash. This process has been identified as the main source of evaporation that explains the difference between intercepted water and measured evaporation in studies carried out in banana plants (Bassette and Bussière, 2008) and eucalyptus plantations (Dunin et al., 1988).

Forest evaporation produces coherent structures of water vapor called plumes, cells, or rolls (Couvreux et al., 2010). Plumes of water vapor have been identified above forest ecosystems during the daytime with a high-resolution scanning Raman lidar technique (Cooper et al., 2006; Kao et al., 2000). These plumes reached heights above the canopy up to $100 \mathrm{~m}$, depicting their importance as water vapor providers at local scale. This phenomenon has been studied in astrophysics (Berg et al., 2016; Sparks et al., 2019), vulcanology (Kern et al., 2017; Sioris et al., 2016), and regional and global meteorology (Herman et al., 2017; Knoche and Kunstmann, 2013; Wang, 2003; Wright et al., 2017). However, to the best of our knowledge, little attention has been paid to the small events observed during rain events. Additionally, Couvreux et al. (2010) highlighted the lack of sampling techniques able to characterize the occurrence of these plumes close to the surface. Visible vapor plumes are classified as ascending clouds formed by clusters of tiny particles of water in liquid form (Spellman, 2012). This characteristic makes it difficult to measure them with sophisticated systems based on 3D wind components (e.g., eddy-covariance systems) that are developed to measure water in gas form (Foken et al., 2012a). These types of measurements are sensitive to rainy and high-humidity conditions (Camuffo, 2019; Foken et al., 2012b; Kelton and Bricout, 1964; Moncrieff et al., 2005; Mauder and Zeeman, 2018; Peters et al., 1998), making it difficult to use them to identify the occurrence of visible vapor plumes in forested ecosystems. This mismatch between measurement systems and target phenomena underlines the need to identify the conditions under which visible vapor plumes are formed. This type of constraint requires an innovative data analysis approach, which is the focus of this paper. This work aims (1) to test an innovative approach to link visual information and conventional meteorological data describing a local hydrological phenomenon. It also aims (2) to identify the meteorological conditions when visible vapor plumes are present in a tropical wet forest and it tries (3) to explain the processes involved in the formation of these plumes. The data analysis is based on conventional meteorological data vertically distributed along the forest canopy layer and time-lapse videos during daytime conditions.

\section{Methodology}

\subsection{Study site}

The monitoring was carried out at La Selva Biological Station (LSBS) on the Caribbean lowlands of Costa Rica $\left(10^{\circ} 26^{\prime} 00^{\prime \prime} \mathrm{N}, 83^{\circ} 59^{\prime} 00^{\prime \prime} \mathrm{W}\right)$. This station registered a mean annual precipitation of $4351 \mathrm{~mm} \mathrm{yr}^{-1}$, a mean annual temperature of $26.3^{\circ} \mathrm{C}$, and a mean daily temperature difference of $9.5^{\circ} \mathrm{C}$. A short dry season occurs at LSBS between February and April every year, and it is characterized by a reduction in precipitation without the vegetation experiencing a soil water deficit (Sanford et al., 1994; Lieberman and Lieberman, 1987; Loescher et al., 2005). LSBS is covered by a matrix of old-growth and secondary forests, small forest plantations, and experimental permanent plots with mixed tree species (Fig. 1). All instrumentation was placed within the area of 1.0 ha of the major research infrastructure plot (MRI plot), located within an old-growth forest on the upper terrace of the Puerto Viejo river (Sanford et al., 1994). The MRI plot is situated in the upper section of a small hill facing southwest towards an affluent of the Puerto Viejo river. The soil is classified as Andic Humidotropept with a clay and organic matter content of $35 \%$ and $23 \%$, respectively (Sollins et al., 1994). The tree density in 2017 was 371 trees ha $^{-1}$ of individuals with a tree diameter bigger than $10 \mathrm{~cm}$. The palm Welfia regia $\mathrm{H}$. Wendl and the tree Pentaclethra macroloba (Willd.) Kuntze are the most abundant species with 56 and 43 trees ha $^{-1}$, respectively. The average leaf area index (LAI) in 2005 was $3.56 \mathrm{~m}^{2} \mathrm{~m}^{-2}$ (Tang et al., 2012). The plot is located within a stable forest plot in terms of changes in canopy height and tree biomass fixation (Dubayah et al., 2010).

\subsection{Experimental design}

The monitoring was carried out on the MRI plot in the highest tower $(43 \mathrm{~m})$, which is located within a depression of the forest canopy (Fig. 1). Along the vertical axis of the tower the air temperature $\left({ }^{\circ} \mathrm{C}\right)$ and relative humidity $(\%)$ were measured with $\mathrm{HOBO}^{\circledR}$ smart sensors (part code: S-THB-M008). The sensors were located at 2, 8 , and $43 \mathrm{~m}$ height, placed at a distance of $1.5 \mathrm{~m}$ from the tower, and protected with a radiation shield (HOBO ${ }^{\circledR}$ part code: RS-3) of $10 \mathrm{~cm}$ diameter. The use of radiation shields together with conventional air temperature sensors allows for keeping a mean absolute error during the daytime in warm tropical ecosystems below $0.3^{\circ} \mathrm{C}$ (da Cunha, 2015; Terando et al., 2017). Also, the shelter provided by the forest canopy for the measurements 
carried out at $2 \mathrm{~m}$ helps one record similar temperatures to the surrounding near-surface environment (Lundquist and Huggett, 2008). The measurement of minimum air temperatures or nighttime temperatures does not require the cover of the radiation shield to keep low biases $\left(<0.5^{\circ} \mathrm{C}\right)$ on the mean air temperature due to the reduced or total absence of solar radiation (Terando et al., 2017). At the highest point of the tower, the precipitation $\left(\mathrm{mm} \mathrm{min}^{-1}\right)$ was recorded with a Davis ${ }^{\circledR}$ rain gauge. Soil temperature $\left({ }^{\circ} \mathrm{C}\right)$ was measured in two different locations at 5 and $15 \mathrm{~cm}$ depth with a soil temperature sensor $\left(\mathrm{HOBO}^{\circledR}\right.$ part code: TMC20-HD). Soil moisture $\left(\Theta, \mathrm{m}^{3} \mathrm{~m}^{-3}\right)$ was measured at the same locations as soil temperature at $5 \mathrm{~cm}$ depth with an $\mathrm{ECH}_{2} \mathrm{O}^{\circledR} \mathrm{EC}$ sensor. Soil temperature was recorded with a four-channel data logger $\left(\mathrm{HOBO}^{\circledR}\right.$ part code: U12-008) and the other sensors with a USB Micro Station (HOBO ${ }^{\circledR}$ part code: H21-USB). Meteorological data collected along the tower, as well as soil temperature data were recorded with averages of 1 and $5 \mathrm{~min}$, respectively. All data were summarized in 5 min time intervals for the analysis. A Bushnell ${ }^{\circledR}$ Natureview $^{\circledR}$ Essential HD camera (12 megapixels) was installed at the top of the tower facing northwest.

\subsection{Monitoring period}

All environmental variables were monitored between 24 January 2018 and 26 March 2018. The camera was installed to collect photographs above the canopy between 21 and 25 March 2018. The photographs were set to be collected continuously from 05:00 to 18:30 local time (UTC-6). However, the light conditions determined which images were selected for analysis (see Appendix A). These pictures were used to determine when the vapor plumes were visible at the MRI plot. The photographs were classified into three conditions (Fig. 2):

- Clear view includes all the pictures with clear and cloudy sky where the canopy is clearly visible and there is neither mist nor plumes present (Fig. 2a and b).

- Mist and fog include the presence of a homogeneous blurry view of the canopy. The blurriness of each picture varies depending on the humidity conditions. Special care was taken to prevent the erroneous classification of photographs affected by a fogged-up lens. This category is subsequently called "mist" (Fig. 2c).

- Plumes include the presence of buoyant vapor clouds rising from the forest canopy (Fig. 2d). These cloud bodies change their vertical position in consecutive frames. Rising vapor plumes can be observed in the online video of 24 March 2018 available at https://doi.org/10.4121/uuid:997cc9d8-2281453e-b631-5f93cfebe00e (Jiménez-Rodríguez et al., 2019b).

\subsection{Data analysis}

Data processing and analysis was performed with the opensource software R (R Core Team, 2017). All temperatures were converted from $\mathrm{K}$ to ${ }^{\circ} \mathrm{C}$. Superficial soil temperature $\left(T_{\mathrm{s} .0},{ }^{\circ} \mathrm{C}\right)$ was estimated with Eq. (1) (Holmes et al., 2008). This equation describes the diurnal variations of soil temperature as sine waves depending on the $24 \mathrm{~h}$ moving averages of soil temperature at $5 \mathrm{~cm}$ depth $\left(T_{\mathrm{s} .5},{ }^{\circ} \mathrm{C}\right)$. The daily amplitude of air temperature $\left(T_{\mathrm{A}},{ }^{\circ} \mathrm{C}\right)$ is defined as the difference between $T_{\mathrm{s} .5}$ and the air temperature at $2 \mathrm{~m}\left(T_{2 \mathrm{~m}}\right)$. The oscillations are determined by the damping depth $(\nu, \mathrm{m})$, which is calculated with Eq. (2). The depth difference between the $T_{\mathrm{s} .0}$ and $T_{\mathrm{s} .5}$ is defined as $z_{\mathrm{b}}(\mathrm{m})$. The sine pattern depends on the angular frequency $\left(\omega, \mathrm{s}^{-1}\right)$, time $(t)$ in $\mathrm{s}$, and $\phi(-)$ as a constant for phase change. Equation (3) is used to determine $\omega$ with $\tau$ (s) as the wave period. Equation (2) calculates $v$ with the soil thermal diffusivity $\left(\eta, \mathrm{m}^{2} \mathrm{~s}^{-1}\right)$ and $\omega$. Equation (4) (Nakshabandi and Kohnke, 1965) is used to determine $\eta$, where $\rho_{\mathrm{s}}$ is the soil bulk density of $0.76 \mathrm{~g} \mathrm{~cm}^{-3}$ (Sollins et al., 1994) for the experimental plot, $c_{\mathrm{S}}$ is the specific heat for clay soils $\left(837.36 \mathrm{~W} \mathrm{~kg}^{-1}{ }^{\circ} \mathrm{C}^{-1}\right)$, and $k$ is the soil thermal conductivity of $1.58 \mathrm{~W} \mathrm{~m}^{-1}{ }^{\circ} \mathrm{C}^{-1}$ (Pielke, 2013). The last two parameters were chosen according to the soil water conditions during the monitoring period, which was close to soil field capacity (see Appendix B).

$$
\begin{aligned}
& T_{\mathrm{s} .0}=T_{\mathrm{s} .5}+T_{\mathrm{A}} e^{\left(\frac{-z_{\mathrm{b}}}{v}\right)} \sin \left(\omega t-\frac{z_{\mathrm{b}}}{v}+\phi\right) \\
& v=\sqrt{\frac{2 \eta}{\omega}} \\
& \omega=\frac{2 \pi}{\tau} \\
& \eta=\frac{k}{\rho_{\mathrm{s}} c_{\mathrm{s}}}
\end{aligned}
$$

The virtual potential temperature $\left(\theta_{\mathrm{v}},{ }^{\circ} \mathrm{C}\right)$ of the air was calculated to take into account the variation in the adiabatic lapse rate due to changes in pressure (Barr et al., 1994; Stull, 1988, 2017). For saturated (cloudy) air conditions Eq. (5) calculates the $\theta_{\mathrm{v}}$ based on the water vapor mixing ratio $\left(\psi_{\mathrm{s}}\right)$ of the saturated air, the liquid water mixing ratio $\left(\psi_{\mathrm{L}}\right)$, and the virtual temperature $(\theta)$. The parameters $\psi_{\mathrm{s}}$ and $\psi_{\mathrm{L}}$ were determined with Eqs. (7) and (8), respectively. These equations require one to know the mass of the liquid water in the air $\left(m_{\text {liq.air }}\right)$, the mass of the water vapor in the air $\left(m_{\text {vap.air }}\right)$, and the mass of the dry air ( $\left.m_{\text {dry.air }}\right)$. Due to the lack of instrumentation to estimate the mass of liquid water in the air, we used a fixed value of $0.05 \mathrm{~g} \mathrm{~m}^{-3}$. This value corresponds to the liquid water content (LWC) in the air reported by Thompson (2007) for continental fog events. The selection of this value was based on (1) the similarity between the vapor plumes and fog and (2) the fact that both types of events occur close to the ground surface. The variables $m_{\text {vap.air }}$ and $m_{\text {dry.air }}$ were determined using the saturation and actual vapor pressures of the air (Stull, 2017). The virtual temperature 


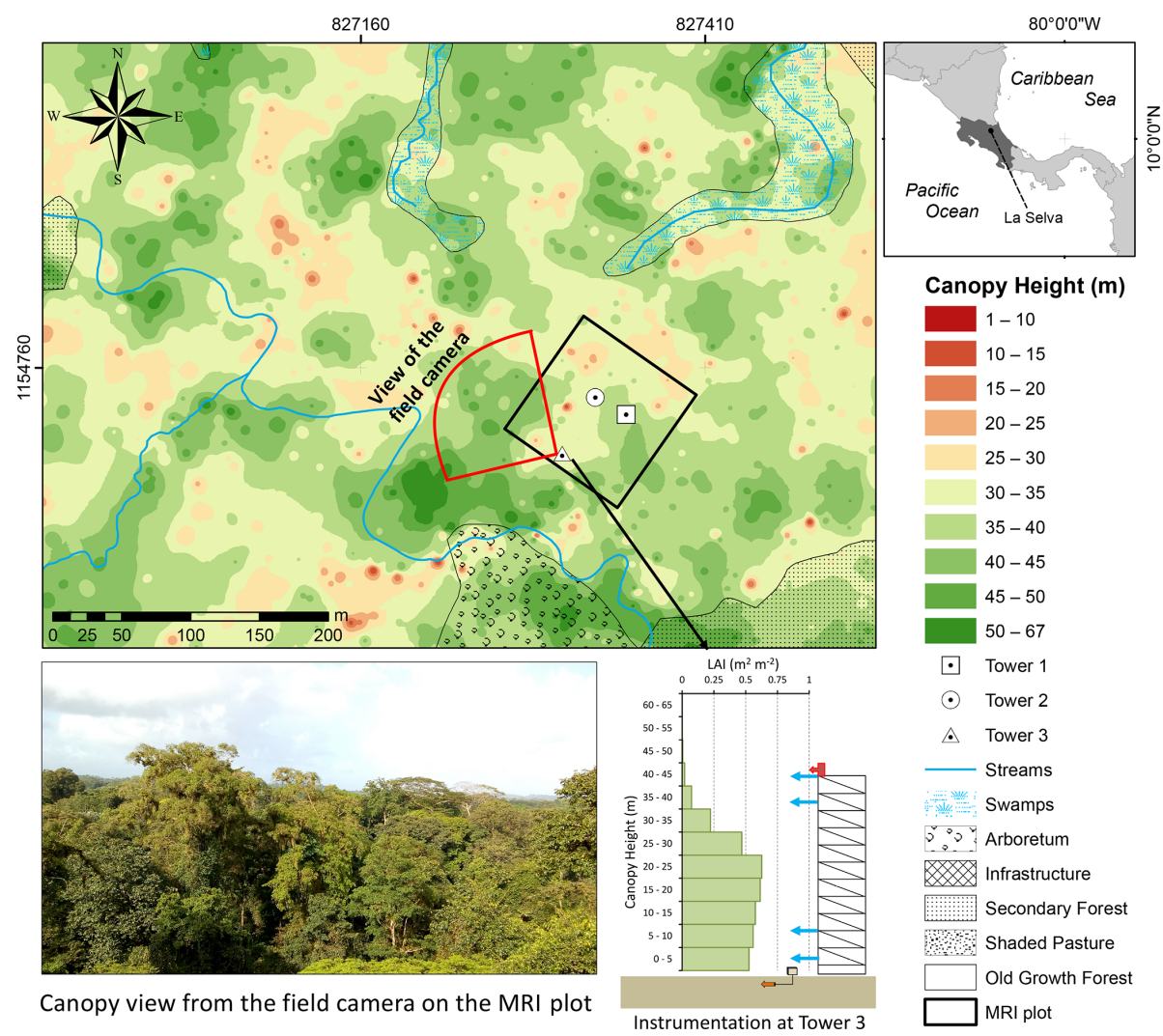

Figure 1. Canopy height and land cover map of the area surrounding the major research infrastructure plot (MRI plot) at La Selva Biological Station, Costa Rica. The photograph shows the view from the field camera at the top of the tower.

was estimated with Eq. (6), where $\Gamma_{\mathrm{d}}$ is the dry adiabatic lapse rate near the surface $\left(0.0098^{\circ} \mathrm{Cm}^{-1}\right), z$ is the height above the ground in meters, and $T_{z}$ is the air temperature at the same heights.

$\theta_{\mathrm{v} . z}=\theta_{z}\left(1+0.608 \psi_{\mathrm{s}}-\psi_{\mathrm{L}}\right)$

$\theta_{z}=T_{z}+\Gamma_{\mathrm{d}} z$

$\psi_{\mathrm{s}}=\frac{m_{\text {vap.water }}}{m_{\text {dry.air }}}$

$\psi_{\mathrm{L}}=\frac{m_{\text {liq.water }}}{m_{\text {dry.air }}}$

Convection can be identified by evaluating the temperature gradient $\left(\frac{\Delta \theta_{\mathrm{v}}}{\Delta z}\right)$ due to the absence of wind profile measurements to determine the atmospheric stability parameter along the tower. Values of $\frac{\Delta \theta_{\mathrm{v}}}{\Delta z}>0$ are linked to stable stratification; meanwhile, $\frac{\Delta \theta_{\mathrm{v}}}{\Delta z}<0$ shows an unstable stratification (Stull, 2017), which will drive convection.

The condensation of vapor close to the forest canopy can be identified by calculating the lifting condensation level $\left(z_{\text {lcl }}\right)$ in meters with Eq. (9). This equation determines the elevation at which a parcel of air condensates allowing the formation of clouds. This equation uses the difference between air temperature $\left(T_{z}\right)$ and dew point temperature $\left(T_{\text {dew.z. }}\right)$ at one specific height $(z)$, divided by the difference between $\Gamma_{\mathrm{d}}$ and the dew point temperature lapse rate $\left(\Gamma_{\text {dew }}\right)$ (Stull, 2017).

$z_{\mathrm{lcl}}=\frac{T_{z}-T_{\mathrm{dew} . z}}{\Gamma_{\mathrm{d}}-\Gamma_{\mathrm{dew}}}$

An estimation of the evaporation during the monitored period was retrieved from Jiménez-Rodríguez et al. (2020). This data set is used only as a reference for the evaporation process during the monitoring period on the same site. This is because this quantification has limitations accomplishing the Monin-Obukhov similarity theory (MOST) for complex terrains (Breedt et al., 2018). So, it is based only on the vertical transport of water vapor, neglecting the advected energy of the forest canopy.

\section{Results and discussion}

The monitoring period experienced a diurnal variation in air temperature along the vertical profile of the canopy, with a temperature difference of more than $10^{\circ} \mathrm{C}$ at $43 \mathrm{~m}$ and less than $7{ }^{\circ} \mathrm{C}$ at $2 \mathrm{~m}$ height (Fig. 3). The highest temperatures were registered at $43 \mathrm{~m}$ height reaching more than $30^{\circ} \mathrm{C}$, decreasing in magnitude towards the forest floor. These peak temperatures were recorded around noon with differences up to $5^{\circ} \mathrm{C}$ between the air temperatures at 43 and $2 \mathrm{~m}$ height. 


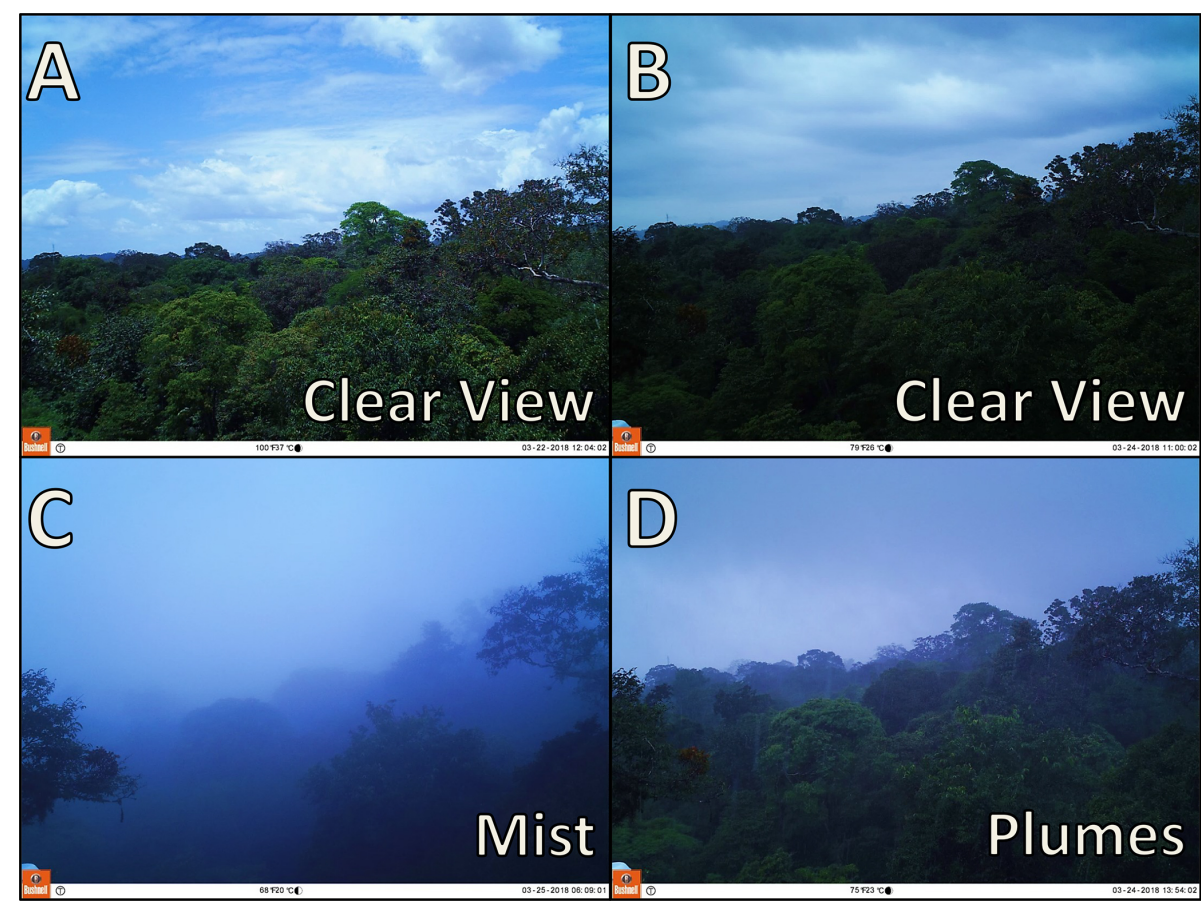

Figure 2. Visual monitoring showing the three conditions used to classify the canopy photographs on the time-lapse videos. The pictures (a) and (b) show the clear view classification, with picture (a) on a sunny day and picture (b) during rain. Picture (c) describes the mist and picture (d) shows the plumes rising from the forest canopy.

The $T_{\mathrm{s} .0}$ oscillates between 20.7 and $25.4^{\circ} \mathrm{C}$. The amplitude of the oscillation increased with the sunniest days, but the daily difference did not exceed $4{ }^{\circ} \mathrm{C}$. The maximum $\Theta$ value was $0.47 \mathrm{~m}^{3} \mathrm{~m}^{-3}$ during the heavy rains, almost reaching the saturation point for clay soils of $0.50 \mathrm{~m}^{3} \mathrm{~m}^{-3}$ (Saxton and Rawls, 2006). The minimum $\Theta$ was recorded after the driest period just before the rains on 24 March $2018\left(0.42 \mathrm{~m}^{3} \mathrm{~m}^{-3}\right)$, getting close to soil field capacity for clay soils (Saxton and Rawls, 2006). Evaporation always occurred during daytime on all sampling days (Fig. 3). During the four sunny days, the evaporation was larger than $5 \mathrm{~mm} \mathrm{~d}^{-1}$, with a contribution of more than $1.0 \mathrm{~mm} \mathrm{~d}^{-1}$ from $8 \mathrm{~m}$ height and no more than $0.7 \mathrm{~mm} \mathrm{~d}^{-1}$ from $2 \mathrm{~m}$ height (Jiménez-Rodríguez et al., 2020). In contrast, on 24 March 2018 the continuous rains summed up to $58.7 \mathrm{~mm} \mathrm{~d}^{-1}$ and the evaporation was estimated as $1.8 \mathrm{~mm} \mathrm{~d}^{-1}$ at $43 \mathrm{~m}$ and only $0.2 \mathrm{~mm} \mathrm{~d}^{-1}$ at $2 \mathrm{~m}$ height (Table 1).

During the visual monitoring with the field camera, clear view conditions were predominant along four days (Fig. 3). These days were characterized by sunny conditions with temperatures above the $25^{\circ} \mathrm{C}$, no large rain events, and a decreasing trend in soil moisture. These days were characterized by cumulus clouds crossing the sky above the forest canopy in the daytime. Any water vapor ascending from the forest canopy needed to reach a height of more than $100 \mathrm{~m}$ to form visible vapor plumes (Fig. 3). Also, on 24 March 2018 it was possible to identify three short periods with
Table 1. Daily summary of precipitation and evaporation at 43,8 , and $2 \mathrm{~m}$ height according to Jiménez-Rodríguez et al. (2020) for the experimental site during the monitoring period.

\begin{tabular}{lrrrr}
\hline \multirow{2}{l}{ Date } & Precipitation & \multicolumn{3}{c}{ Evaporation $\left(\mathrm{mm} \mathrm{d}^{-1}\right)$} \\
\cline { 2 - 5 } & $\left(\mathrm{mm} \mathrm{d}^{-1}\right)$ & $0-43 \mathrm{~m}$ & $0-8 \mathrm{~m}$ & $0-2 \mathrm{~m}$ \\
\hline $2018-03-21$ & 0.0 & 6.0 & 1.5 & 0.7 \\
$2018-03-22$ & 0.0 & 5.4 & 1.1 & 0.4 \\
$2018-03-23$ & 4.6 & 5.8 & 1.1 & 0.3 \\
$2018-03-24$ & 58.7 & 1.8 & 0.5 & 0.2 \\
$2018-03-25$ & 0.0 & 5.3 & 1.2 & 0.5 \\
\hline
\end{tabular}

Note: all evaporation values correspond to the water vapor produced from the forest floor up to the specified height.

clear view conditions in between the rains. Mist formation was identified on 23 and 25 March 2018 before 07:00. Mist might have been formed early in the morning during the 21 and 22 March 2018 sampling dates. However, the time-lapse video did not work at those times (Table A1). These mist events were linked with superficial soil temperatures higher than $2{ }^{\circ} \mathrm{C}$ with respect to air temperature. Finally, the vapor plumes were visible only during rainy conditions on 24 March 2018 (videos available at Jiménez-Rodríguez et al., $2019 b)$. Soil temperatures during this day were warmer than the air column along the forest canopy (Fig. 3). 
Evaporation during sunny days provided the conditions to form vapor plumes as those described by Cooper et al. (2006) and Kao et al. (2000). The evaporation peaks during these days occurred around noon, registering a $z_{\text {lcl }}$ higher than $500 \mathrm{~m}$ (Fig. 3), which is the height required to form visible clouds. This is the reason why is not possible to see the vapor rising from the surface. The vapor plumes were visible on the day with continuous precipitation (24 March 2018). On this day, the $z_{\text {lcl }}$ dropped beneath $100 \mathrm{~m}$ because during rain events the $\theta_{\mathrm{v}}$ of all the air columns dropped quickly. This drop kept the $\theta_{\mathrm{v}}$ beneath the superficial soil temperature, allowing a localized convection event. This convection process forced the evaporated water to move upwards, forming buoyant clouds close to the forest surface. The evaporation during rain events is the result of the splash-droplet evaporation process (Murakami, 2006; Dunkerley, 2009), which can provide water vapor as a consequence of the fragmentation of raindrops when hitting the surface.

Energy convection plays an important role in forest ecosystems during the nighttime (Bosveld et al., 1999). This is a consequence of the mass transport capacity of the intermittent nocturnal convective fluxes (Cooper et al., 2006). The convection process is forced by the ground heat flux (Jacobs et al., 1994), which is enhanced by the larger soil moisture in clay soil, which increases the soil heat capacity (Abu-Hamdeh, 2003). A coupled canopy system enables sensible heat and water vapor transport from the soil to the atmosphere just above the canopy layer (Göckede et al., 2007). This facilitates the generation of the convection process, allowing the ascending warm air to cool down at the canopy top and condensate, forming the visible water vapor plumes. The condensation releases heat (Goosse, 2015), driving the convection. Vapor plumes are always present as a consequence of the moisture exchange between the surface and the atmosphere (Lawford, 1996), where evaporation from land cover with enough water supply provides the required air moisture (Kao et al., 2000). However, the conditions needed to form a visible buoyant cloud close to the surface require a big difference in air temperature over height. The temperature gradient at 43,8 , and $2 \mathrm{~m}$ is negative during plumes and mist conditions; meanwhile clear view conditions have a larger range with more positive values (see Appendix C).

The visible vapor plumes can be spotted on the canopy depressions surrounding the tower (Fig. 1). These depressions are characterized by a low leaf area index and shorter canopy height, which translates into areas with low potential to produce transpiration during rain events. This implies that the main source of water vapor is linked to water evaporated from wet surfaces and soil evaporation, while transpiration may contribute to a lesser extent. Visible vapor plumes are the result of the condensation of water vapor rising from a warmer surface. When a column of warm humid air reaches the dew point temperature, the water vapor condensates around aerosols in the air allowing the formation of clouds (Stull, 2017). In this regard, there are different sources of aerosols at LSBS. One source is linked to wind carrying aerosols from nearby agricultural land uses (Loescher et al., 2004). A second source is linked to convective rains that characterize the dry season at LSBS. Additionally, the presence of bioparticles cannot be discarded (e.g., airborne bacteria, fungi, pollen, and plant fragments) as a source of aerosols from the forests (Huffman et al., 2013; Valsan et al., 2015). The high intensity rains may induce a bioparticles burst from the forest canopy. These bioparticles have been reported in Australia (Bigg et al., 2015), India (Valsan et al., 2015), Mexico (Rodriguez-Gomez et al., 2020), and the Amazon (Pöschl et al., 2010). Also, convective rains transport a portion of the required aerosols for the condensation process from the free troposphere into the boundary layer and later they form clouds (Wang et al., 2016). Meanwhile, the splashdroplet evaporation process (Murakami, 2006) provides the main source of water vapor after raindrops hit the canopy and soil surfaces. As plumes are not stagnant and continue moving upwards thanks to air convection, the water vapor is removed from the understory towards higher altitudes. The water condensation at the canopy level drastically reduced the volume of water vapor due to the phase change (Makarieva et al., 2013b). This allowed the ambient air to remain unsaturated allowing the continuous provision of water vapor by the splash-droplet evaporation process continuously more water vapor.

Cloud formation usually happens high above the surface boundary layer where the forest canopy is located, but the available information of cloud formation close to the forest canopy is scarce. The temperature gradient $\left(\frac{\Delta \theta_{\mathrm{v}}}{\Delta z}\right)$ at 43,8 , and $2 \mathrm{~m}$ is negative during plumes and mist conditions, while clear view conditions have a larger range with more positive gradients. Lifting condensation level is a key element that allowed us to differentiate between plumes and mist conditions (see Appendix C). The combination of variables such as $z_{\text {lcl }}, \frac{\Delta \theta_{\mathrm{v}}}{\Delta z}$, and $P$ allows one to identify the formation of vapor plumes in tropical wet forests (Fig. 4). The $z_{\text {lcl }}$ is the height in the atmosphere at which a parcel of moist air becomes saturated if it experiences a forced ascent (Stull, 2017). It provides an estimate of the height at which the clouds can be formed. The temperature gradient is an indicator of how easily a parcel of air can be lifted (Spellman, 2012) and can be used as a proxy of the atmospheric stability. During unstable atmospheric conditions $\left(\frac{\Delta \theta_{\mathrm{v}}}{\Delta z}<0\right)$ it is easier for the air parcels to move upwards than under stable conditions $\left(\frac{\Delta \theta_{\mathrm{v}}}{\Delta z}>0\right)$. Finally, precipitation saturates the air column and provides the water vapor after the splash-droplet evaporation process on the canopy and forest floor surfaces.

During the full monitoring period at LSBS, only $1.4 \%$ of our study period accomplished the conditions required for the formation of visible vapor plumes (precipitation, $z_{\text {lcl }}<$ $100 \mathrm{~m}$, and $\left.0>\frac{\Delta \theta_{\mathrm{v}}}{\Delta z}>-1\right)$. These conditions differ from those needed to form mist. In a tropical wet forest in Costa Rica, fog and mist formation happens before sunrise (Allen et al., 1972). However, fog does not involve the upward con- 

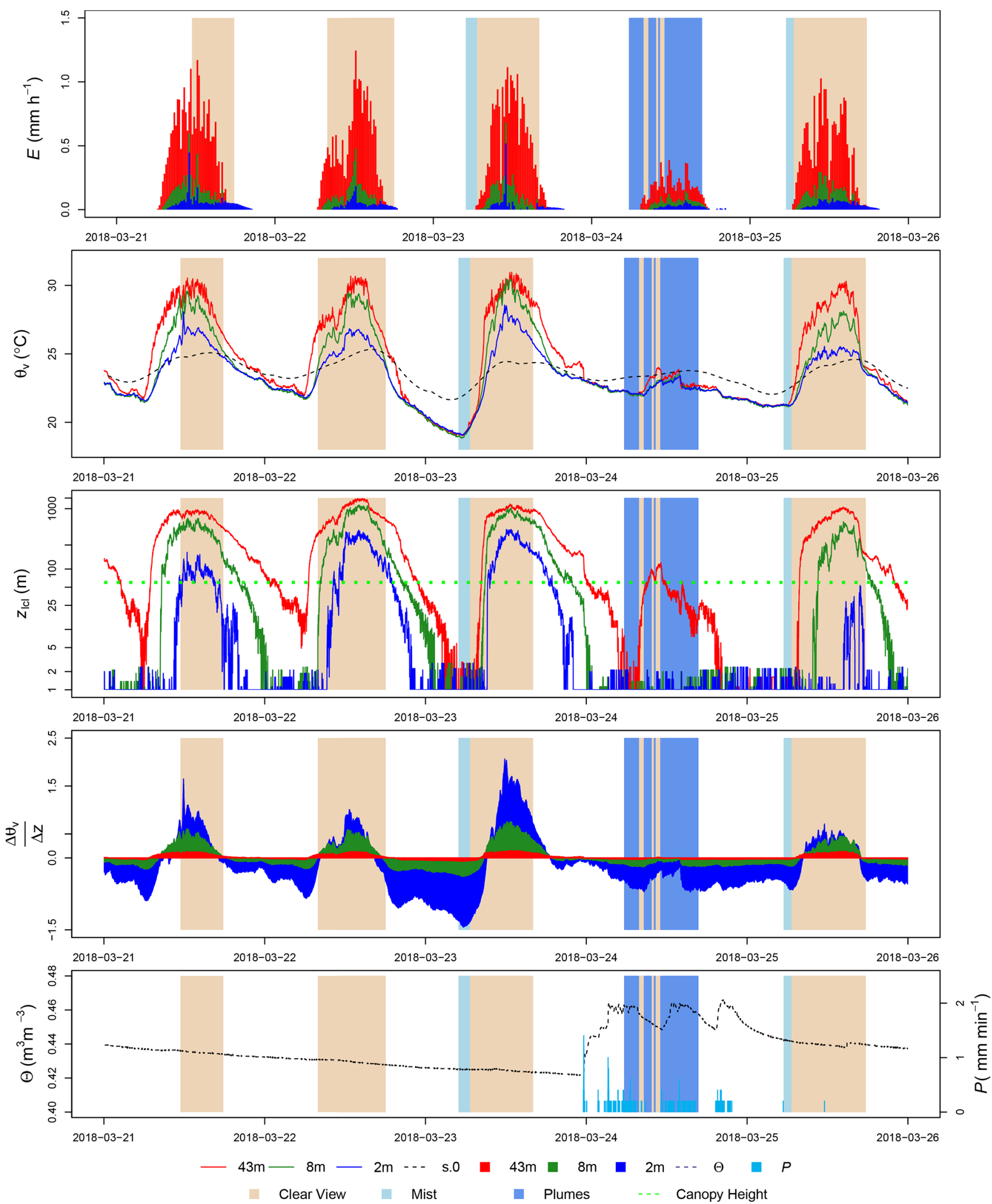

Figure 3. Virtual potential temperature $\left(\theta_{\mathrm{v}}\right)$, lifting condensation level $\left(z_{1 \mathrm{cl}}\right)$ in an untransformed semilogarithmic scale, and temperature gradient $\left(\frac{\Delta \theta_{\mathrm{v}}}{\Delta z}\right)$ at 43,8 and $2 \mathrm{~m}$ height. Additionally, precipitation $(P)$ and soil moisture $(\Theta)$ are shown during the visual monitoring between 21 and 25 March 2018. Evaporation $(E)$ measurements were retrieved from Jiménez-Rodríguez et al. (2020). Background-colored areas denote the three categories in which the photographs were classified: clear view, mist, and plumes. 


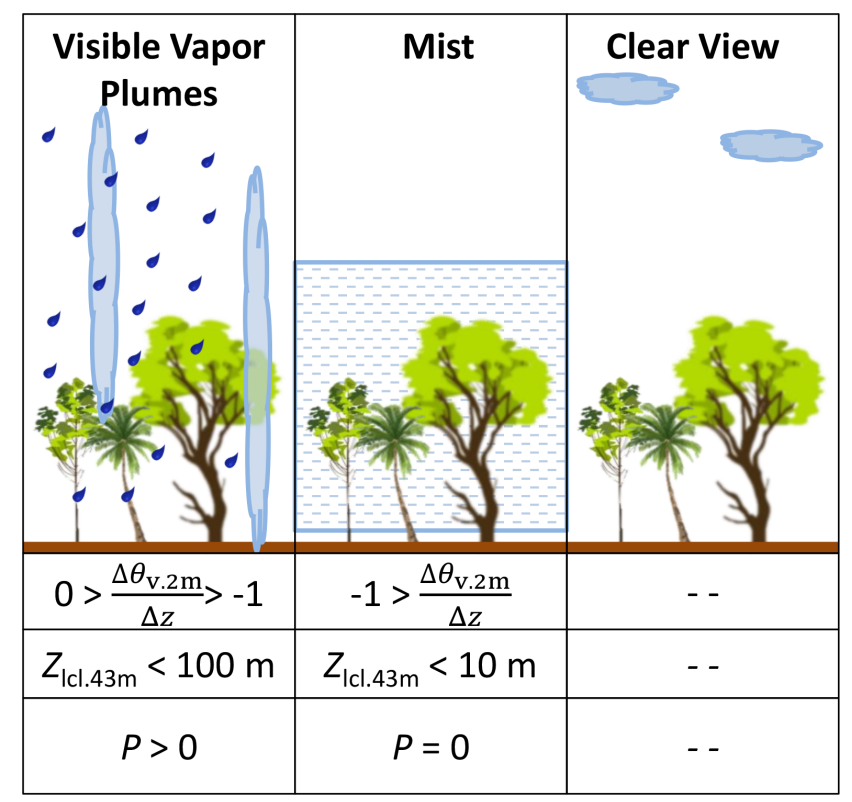

Figure 4. Simplification diagram describing the required conditions to form visible vapor plumes in a tropical wet forest and the differences between mist and clear view conditions.

vective flux needed for vapor plumes, while mist is affected by this upward convective flux but without rain (Stull, 2017). Vapor plumes are buoyant cloud formations with an identifiable shape (Spellman, 2012), which is the main characteristic that allows differentiation between fog and mist events. Mist and fog are formed by microscopic water droplets floating in the air, which can reduce the visibility to less than $1 \mathrm{~km}$ in the case of fog or a lesser extent with mist (Spellman, 2012).

This paper described the formation of visible vapor plumes based on photographs as a visual indication of a process that is usually invisible to the human eye. The occurrence of this phenomenon under rainy conditions makes it difficult to quantify its contribution to the forest evaporation with current measuring techniques. Vapor plumes occurring during rainy days compromise the performance of more sophisticated instruments that are highly sensitive to rain or mist conditions (Centre for Atmospheric Science, 2020; Mauder and Zeeman, 2018). Instruments such as sonic anemometers (e.g., CSAT3, CSAT3B) and open-path $\mathrm{CO}_{2} / \mathrm{H}_{2} \mathrm{O}$ analyzers (e.g., LI-7500) are strongly affected by high humidity and rainfall (Campbell Scientific Inc., 2017, 2019; Foken et al., 2012a; LI-COR, 2016; Moncrieff et al., 2005). The presence of rain causes departures from the measurements, increasing the sonic speed (Camuffo, 2019; Kelton and Bricout, 1964; Peters et al., 1998) or blocking the face of the transducers (Campbell Scientific Inc., 2017), causing a frequency loss during rain events (Zhang et al., 2016). The eddy-covariance technique is considered the standard measurement for determining atmospheric fluxes; however, it is dependent on fully turbulent transport over a homogeneous surface (Foken et al., 2012a). This means that the localized nature of the visible vapor plumes makes measuring them very susceptible to sensor placement, complicating its monitoring using eddycovariance systems located high above the canopy. Additionally, measuring devices based on 3D wind components (e.g., eddy-covariance systems) are developed to measure water in gas form (Foken et al., 2012a) and are not intended to measure visible vapor plumes that are ascending clusters of tiny water particles (Spellman, 2012).

The description of the formation process of visible vapor plumes provides a first step towards understanding this phenomenon within forest hydrology. This description helps identify when this phenomenon occurs, allowing one to screen existing data sets in other tropical research sites to analyze its frequency of occurrence. However, it is important to test if the conditions required to form visible vapor plumes are the same in other latitudes and ecosystems. Also, new developments in air temperature monitoring techniques, such as distributed temperature sensing (Euser et al., 2014; Heusinkveld et al., 2020; Izett et al., 2019; Schilperoort et al., 2018) or thermal infrared imagery (Costa et al., 2019; Egea et al., 2017; Lapidot et al., 2019; Nieto et al., 2019), may contribute to accurately quantify the contribution of visible vapor plumes as local recyclers of forest evaporation. These methods are suitable alternatives to eddy-covariance systems that are sensitive to rainy conditions when visible vapor plumes occur.

Understanding the formation process is a prerequisite before the quantification of such a complex process. Further studies aiming to analyze the occurrence of visible vapor plumes in more detail will need to consider the conditions that give origin to this phenomenon: air convection, precipitation presence, and lifting condensation level at the top of the canopy. While the quantification of its contribution to the hydrological cycle have to overcome the limitations of current measuring techniques. The identification of air convection should be based on direct measurements of ground heat flux (e.g., soil heat flux plates), a more detailed air temperature profile along the forest canopy (e.g., using distributed temperature sensing), and multiple wind speed measurements along the canopy profile (e.g., at least one per canopy layer plus one above the canopy). This set of measurements will help identify air convection and advection within the canopy structure. The wind measurements should be carried pairing sonic and cup anemometers at the same locations, allowing one to overcome the limitations of sonic anemometers during rain events (Mauder and Zeeman, 2018), when liquid water covers the ultrasonic transducers.

The evaporation contribution to the local hydrological cycle by visible vapor plumes requires a detailed quantification of the latent heat flux $(\rho \lambda E)$ above and below the canopy. The use of net radiometers at different heights (same locations as wind speed measurements) will complement the detailed air temperature and wind speed measurements. It is important to underline that some experimental sites worldwide 
accomplish the equipment requirements mentioned above (FLUXNET, 2020), opening the opportunity to reanalyze their data sets towards the identification of the conditions needed for the formation of visible vapor plumes. Also, these sites provide an opportunity to quantify the bias that eddycovariance systems have due to the existence of this phenomenon. Direct measurements of atmospheric water (gas and liquid phase) can be achieved with closed-path gas analyzers (e.g., LI-7000DS-LI-COR, EC155-Campbell Sci., FMA-Los Gatos Research), allowing one to determine the total water content in the air. These measurements will benefit from combining high-resolution infrared images from above and below the canopy, allowing one to study the spatial distribution of the phenomenon. These images will provide information under day and night conditions, helping one to identify the splash-droplet evaporation process at canopy and ground level when the view field is focused towards specific locations of the forest canopy. Finally, further research can search for the detailed source of vapor with the implementation of the direct measurement of water stable isotopes using mass spectrometers or cavity output spectroscopy. This type of research can provide more insights into the effect of vapor plumes on the microclimate of forest ecosystems. Moreover, the occurrence of this phenomenon in other vegetation types may be addressed to understand the main drivers and the role played in local hydrological systems.

\section{Conclusions}

Visual monitoring captured the formation of visible vapor plumes close to the surface boundary layer of a tropical wet forest during rainy conditions. These visible plumes are the visual evidence of evaporation processes happening during rain events, where the splash-droplet evaporation process provides the required water vapor to form visible vapor plumes. This water vapor is part of the intercepted water evaporated from the forest floor and plant surfaces since transpiration is likely reduced by the low vapor pressure deficit but not stopped. It is raised by air convection, driven by warm soil temperatures, finally condensing close to the forest canopy due to the drop in the virtual potential air temperature along the forest air column. Consequently, this phenomenon can be identified in tropical wet forest when precipitation occurs, the lifting condensation level at $43 \mathrm{~m}$ height $\left(z_{\text {lcl }}\right)$ is lower than $100 \mathrm{~m}$, and the temperature gradient $\left(\frac{\Delta \theta_{\mathrm{v}}}{\Delta z}\right)$ at $2 \mathrm{~m}$ height is between 0 and $-1{ }^{\circ} \mathrm{Cm}^{-1}$. Contrary to the vapor plumes, mist appears when no precipitation occurs $(P=0)$, $z_{1 \mathrm{cl}}$ at $43 \mathrm{~m}$ is less than $10 \mathrm{~m}$, and $\frac{\Delta \theta_{\mathrm{v}}}{\Delta z}$ is less than $-1^{\circ} \mathrm{C} \mathrm{m}^{-1}$. This work also brings attention to the forest evaporation role during rain events, where little information is available. The exploratory nature of this work opened new research opportunities aiming to improve the setup to monitor this phenomenon and provide a further accurate quantification of the contribution within the local hydrology. 
Appendix A: Time-lapse videos detailed information

Table A1. Time windows with suitable images for analysis during the five sampling days surveyed with the camera.

\begin{tabular}{llrr}
\hline Sampling date & Time interval & Initial time & Final time \\
\hline $2018-03-21$ & $5 \mathrm{~min}$ & $11: 27$ & $17: 45$ \\
$2018-03-22$ & $5 \mathrm{~min}$ & $08: 00$ & $11: 00$ \\
$2018-03-22$ & $1 \mathrm{~min}$ & $11: 00$ & $18: 00$ \\
$2018-03-23$ & $1 \mathrm{~min}$ & $05: 10$ & $16: 42$ \\
$2018-03-24$ & $1 \mathrm{~min}$ & $05: 30$ & $16: 42$ \\
$2018-03-25$ & $1 \mathrm{~min}$ & $05: 32$ & $17: 38$ \\
\hline
\end{tabular}

Note: the change of sampling intervals from 5 to 1 min was carried out on the second day of video monitoring, with the aim of improving the quality of the survey. The camera was set to take images from 05:00 to 18:30; the time windows showed in the table correspond to the period with images suitable for analysis. 
Appendix B: Daily variables measured at the MRI plot
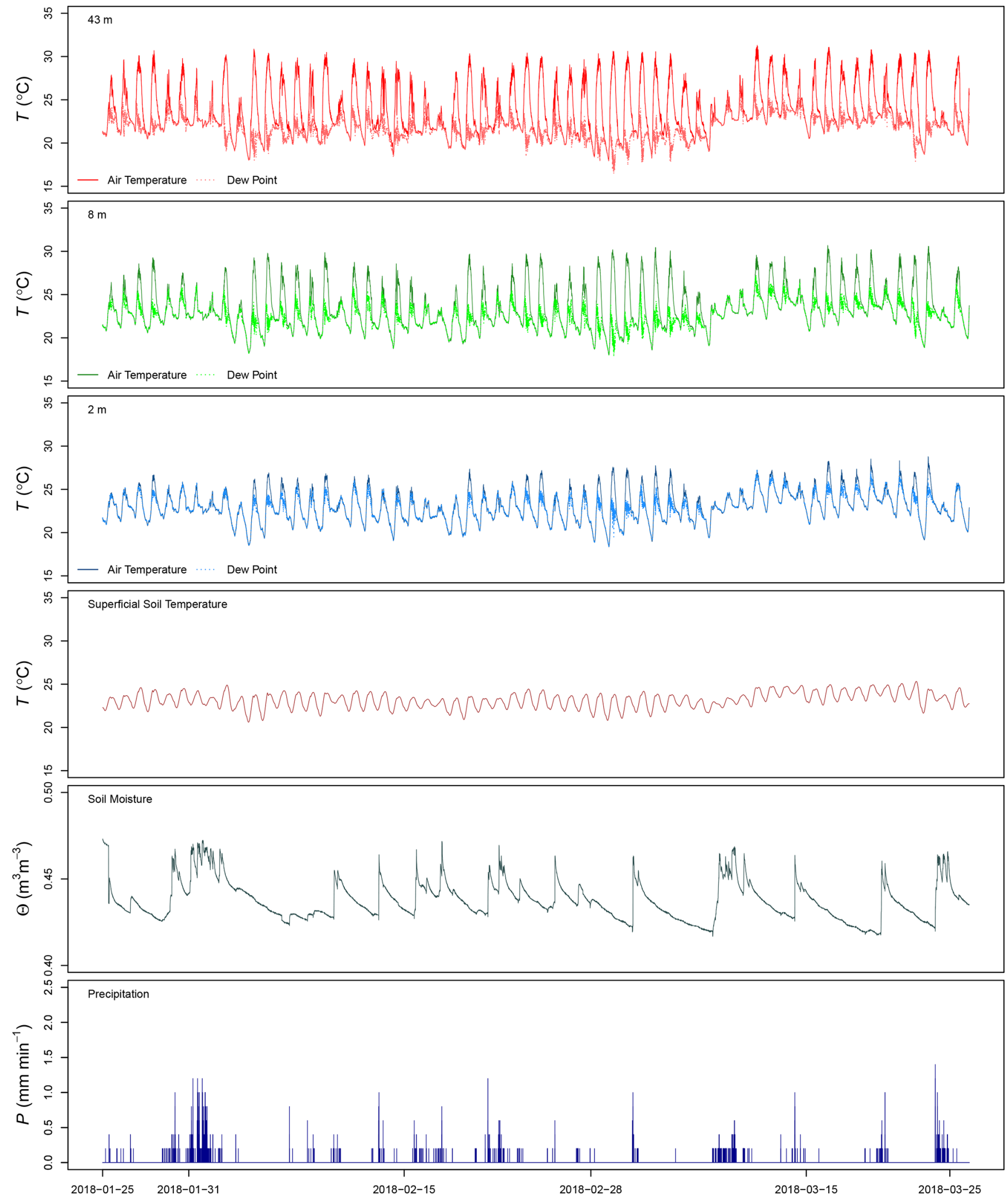

Figure B1. Detailed measurements performed at the MRI plot between 24 and 26 March 2018 along the canopy and within the soil. 


\section{Appendix C: Boxplots}
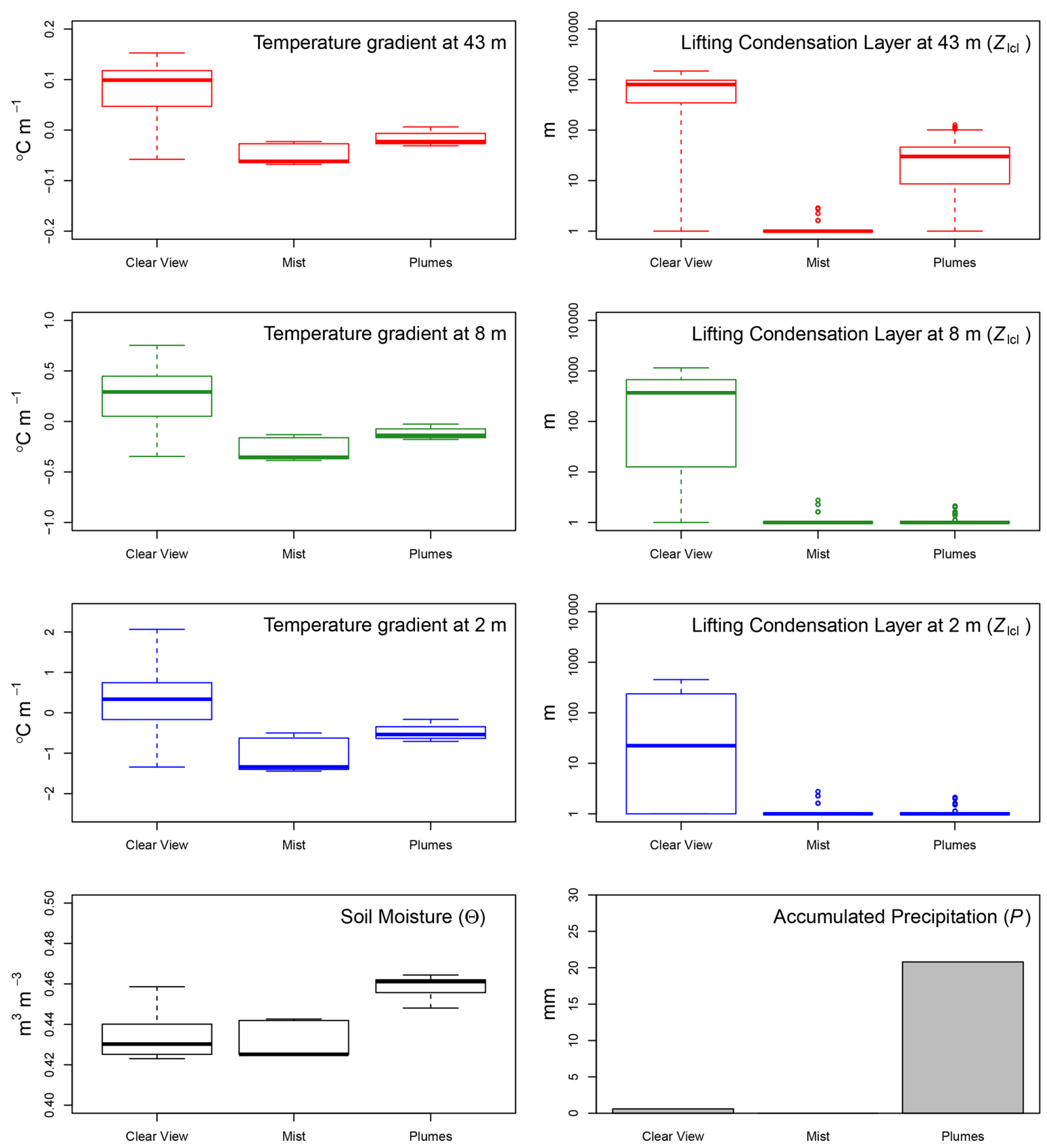

Figure C1. Boxplots describing the temperature gradients $\left(\frac{\Delta \theta_{\mathrm{v}}}{\Delta z}\right)$ and lifting condensation level $\left(z_{\mathrm{lcl}}\right)$ at 43,8 , and $2 \mathrm{~m}$, as well as soil moisture $(\Theta)$ and total precipitation $(P)$ of the three visual categories evaluated. 
Code availability. The $\mathrm{R}$ script used for the data analysis is available online in the 4TU data repository at https://doi.org/10.4121/13720795 (Jiménez-Rodríguez et al., 2021).

Data availability. Time-lapse videos are available online in the 4TU data repository at https://doi.org/10.4121/uuid:997cc9d82281-453e-b631-5f93cfebe00e (Jiménez-Rodríguez et al., 2019b). Meteorological data used in this manuscript are available online in the 4TU data repository (https://doi.org/10.4121/uuid:e70993d25852-4f63-9aff-39451fbd3fde; Jiménez-Rodríguez et al., 2019a).

Author contributions. The project conceptualization and funding acquisition was carried out by CDJR and MCG. The investigation and data curation was carried out by AdPGA and CDJR. Data analysis was performed by BS and CDJR. Finally, the project administration, writing of the original manuscript, and data visualization was carried out by CDJR with input from all coauthors.

Competing interests. The authors declare that they have no conflict of interest.

Acknowledgements. This work was carried out with a fellowship from the Organization for Tropical Studies (Glaxo Centroamerica Fellowship-Fund 502), with the aid of a scholarship from PINNMICITT Costa Rica (contract: PED-032-2015-1), and the aid of grant 863.15.022 from The Netherlands Organization for Scientific Research (NWO). Also, NASA's funding NNX12AN43H and 80NSSC18K0708 provided the Leaf Area Index data sets. Special thanks to Bernal Matarrita, Orlando Vargas, Wagner López, Danilo Brenes, Diego Dierick, Enrique Castro, and Marisol Luna for their help and advice at the research station, to all the staff of the OTS for their willingness to support our project, and to Shigeki Murakami and one anonymous reviewer who helped to improve the paper.

Financial support. This research was supported by the Organization for Tropical Studies (Glaxo Centroamerica FellowshipFund 502 grant), the PINN-MICITT Costa Rica (grant no. PED032-2015-1), The Netherlands Organization for Scientific Research (NWO) (grant no. 863.15.022), and NASA (grant nos. NNX12AN43H and 80NSSC18K0708).

Review statement. This paper was edited by Laurent Pfister and reviewed by Shigeki Murakami and one anonymous referee.

\section{References}

Abu-Hamdeh, N. H.: Thermal Properties of Soils as affected by Density and Water Content, Biosyst. Eng., 86, 97-102, https://doi.org/10.1016/S1537-5110(03)00112-0, 2003.
Adams, D. K., Fernandes, R. M. S., Kursinski, E. R., Maia, J. M., Sapucci, L. F., Machado, L. A. T., Vitorello, I., Monico, J. F. G., Holub, K. L., Gutman, S. I., Filizola, N., and Bennett, R. A.: A dense GNSS meteorological network for observing deep convection in the Amazon, Atmos. Sci. Lett., 12, 207-212, https://doi.org/10.1002/asl.312, 2011.

Allen, L. H., Lemon, E., and Müller, L.: Environment of a Costa Rican Forest, Ecology, 53, 102-111, https://doi.org/10.2307/1935714, 1972.

Allen, S. T., Aubrey, D. P., Bader, M. Y., Coenders-Gerrits, M., Friesen, J., Gutmann, E. D., Guillemette, F., Jiménez-Rodríguez, C., Keim, R. F., Klamerus-Iwan, A., Mendieta-Leiva, G., Porada, P., Qualls, R. G., Schilperoort, B., Stubbins, A., and Van Stan II, J. T.: Key Questions on the Evaporation and Transport of Intercepted Precipitation, 269-280, Springer International Publishing, Cham, https://doi.org/10.1007/978-3-030-29702-2_16, 2020.

Barr, A. G., King, K. M., Gillespie, T. J., Den Hartog, G., and Neumann, H. H.: A comparison of bowen ratio and eddy correlation sensible and latent heat flux measurements above deciduous forest, Bound.-Lay. Meteorol., 71, 21-41, https://doi.org/10.1007/BF00709218, 1994.

Bassette, C. and Bussière, F.: Partitioning of splash and storage during raindrop impacts on banana leaves, Agr. Forest Meteorol., 148, 991-1004, https://doi.org/10.1016/j.agrformet.2008.01.016, 2008.

Berg, J., Goldstein, D., Varghese, P., and Trafton, L.: DSMC simulation of Europa water vapor plumes, Icarus, 277, 370-380, https://doi.org/10.1016/j.icarus.2016.05.030, 2016.

Bigg, E. K., Soubeyrand, S., and Morris, C. E.: Persistent aftereffects of heavy rain on concentrations of ice nuclei and rainfall suggest a biological cause, Atmos. Chem. Phys., 15, 2313-2326, https://doi.org/10.5194/acp-15-2313-2015, 2015.

Bosveld, F. C. and Bouten, W.: Evaluating a Model of Evaporation and Transpiration with Observations in a Partially Wet Douglas-Fir Forest, Bound.-Lay. Meteorol., 108, 365-396, https://doi.org/10.1023/A:1024148707239, 2003.

Bosveld, F. C., Holtslag, A. M., and Van Den Hurk, B. J.: Nighttime convection in the interior of a dense Douglas fir forest, Bound.-Lay. Meteorol., 93, 171-195, https://doi.org/10.1023/A:1002039610790, 1999.

Breedt, H. J., Craig, K. J., and Jothiprakasam, V. D.: MoninObukhov similarity theory and its application to wind flow modelling over complex terrain, J. Wind Eng. Indust. Aerodynam., 182, 308-321, https://doi.org/10.1016/j.jweia.2018.09.026, 2018.

Brubaker, K. L., Entekhabi, D., and Eagleson, P. S.: Estimation of Continental Precipitation Recycling, J. Climate, 6, 1077-1089, https://doi.org/10.1175/15200442(1993)006<1077:EOCPR>2.0.CO;2, 1993.

Campbell Scientific Inc.: CSAT3 Three Dimensional Sonic Anemometer Revision: 4/17, available at: https://s.campbellsci. com/documents/us/manuals/csat3.pdf (last access: 29 June 2020), 2017.

Campbell Scientific Inc.: CSAT3B Three-Dimensional Sonic Anemometer, available at: https://s.campbellsci.com/documents/ us/manuals/csat3b.pdf (last access: 29 June 2020), 2019.

Camuffo, D.: Chapter 20 - Measuring Wind and Indoor Air Motions, in: Microclimate for Cultural Heritage (Third Edition), 
edited by: Camuffo, D., 483-511, Elsevier, third edition edn., https://doi.org/10.1016/B978-0-444-64106-9.00020-1, 2019.

Centre for Atmospheric Science: Sonic Anemometers, available at: http://www.cas.manchester.ac.uk/restools/instruments/ meteorology/sonic/ (last access: 29 June 2020), Department of Earth and Environmental Sciences. The University of Manchester, 2020.

Chen, Q., Fan, J., Hagos, S., Gustafson Jr., W. I., and Berg, L. K.: Roles of wind shear at different vertical levels: Cloud system organization and properties, J. Geophys. Res.-Atmos., 120, 65516574, https://doi.org/10.1002/2015JD023253, 2015.

Cooper, D., Leclerc, M., Archuleta, J., Coulter, R., Eichinger, W., Kao, C., and Nappo, C.: Mass exchange in the stable boundary layer by coherent structures, Agr. Forest Meteorol., 136, 114131, https://doi.org/10.1016/j.agrformet.2004.12.012, 2006.

Costa, J., Egipto, R., Sánchez-Virosta, A., Lopes, C., and Chaves, M.: Canopy and soil thermal patterns to support water and heat stress management in vineyards, Agr. Water Manag., 216, 484496, https://doi.org/10.1016/j.agwat.2018.06.001, 2019.

Couvreux, F., Hourdin, F., and Rio, C.: Resolved Versus Parametrized Boundary-Layer Plumes. Part I: A Parametrization-Oriented Conditional Sampling in LargeEddy Simulations, Bound.-Lay. Meteorol., 134, 441-458, https://doi.org/10.1007/s10546-009-9456-5, 2010.

Curtis, P. G., Slay, C. M., Harris, N. L., Tyukavina, A., and Hansen, M. C.: Classifying drivers of global forest loss, Science, 361, 1108-1111, https://doi.org/10.1126/science.aau3445, 2018.

da Cunha, A. R.: Evaluation of measurement errors of temperature and relative humidity from HOBO data logger under different conditions of exposure to solar radiation, Environ. Monit. Assess., 187, 236, https://doi.org/10.1007/s10661-015-4458-x, 2015.

David, J. S., Valente, F., and Gash, J. H.: Evaporation of Intercepted Rainfall, in: Encyclopedia of Hydrological Sciences, chap. 43, American Cancer Society, https://doi.org/10.1002/0470848944.hsa046, 2006.

Dubayah, R. O., Sheldon, S. L., Clark, D. B., Hofton, M. A., Blair, J. B., Hurtt, G. C., and Chazdon, R. L.: Estimation of tropical forest height and biomass dynamics using lidar remote sensing at La Selva, Costa Rica, J. Geophys. Res.-Biogeosc., 115, G00E09, https://doi.org/10.1029/2009JG000933, 2010.

Dunin, F. X., O'Loughlin, E. M., and Reyenga, W.: Interception loss from eucalypt forest: Lysimeter determination of hourly rates for long term evaluation, Hydrol. Process., 2, 315-329, https://doi.org/10.1002/hyp.3360020403, 1988.

Dunkerley, D. L.: Evaporation of impact water droplets in interception processes: Historical precedence of the hypothesis and a brief literature overview, J. Hydrol., 376, 599-604, https://doi.org/10.1016/j.jhydrol.2009.08.004, 2009.

Egea, G., Padilla-Díaz, C. M., Martinez-Guanter, J., Fernández, J. E., and Pérez-Ruiz, M.: Assessing a crop water stress index derived from aerial thermal imaging and infrared thermometry in super-high density olive orchards, Agr. Water Manag., 187, 210-221, https://doi.org/10.1016/j.agwat.2017.03.030, 2017.

Ellison, D., Morris, C. E., Locatelli, B., Sheil, D., Cohen, J., Murdiyarso, D., Gutierrez, V., van Noordwijk, M., Creed, I. F., Pokorny, J., Gaveau, D., Spracklen, D. V., Tobella, A. B., Ilstedt, U., Teuling, A. J., Gebrehiwot, S. G., Sands, D. C., Muys, B., Verbist, B., Springgay, E., Sugandi, Y., and Sullivan, C. A.: Trees, forests and water: Cool insights for a hot world, Global Environ. Change, 43, 51-61, https://doi.org/10.1016/j.gloenvcha.2017.01.002, 2017.

Euser, T., Luxemburg, W. M. J., Everson, C. S., Mengistu, M. G., Clulow, A. D., and Bastiaanssen, W. G. M.: A new method to measure Bowen ratios using high-resolution vertical dry and wet bulb temperature profiles, Hydrol. Earth Syst. Sci., 18, 20212032, https://doi.org/10.5194/hess-18-2021-2014, 2014.

FLUXNET: Fluxdata, The Data Portal serving the FLUXNET community, available at: https://fluxnet.fluxdata.org/ (last access: 5 April 2020), 2020.

Foken, T., Aubinet, M., and Leuning, R.: The Eddy Covariance Method, pp. 1-19, Springer Netherlands, Dordrecht, https://doi.org/10.1007/978-94-007-2351-1_1, 2012a.

Foken, T., Leuning, R., Oncley, S. R., Mauder, M., and Aubinet, M.: Corrections and Data Quality Control, pp. 85-131, Springer Netherlands, Dordrecht, https://doi.org/10.1007/97894-007-2351-1_4, 2012b.

Fuentes, J. D., Chamecki, M., Nascimento dos Santos, R. M., Von Randow, C., Stoy, P. C., Katul, G., Fitzjarrald, D., Manzi, A., Gerken, T., Trowbridge, A., Souza Freire, L., Ruiz-Plancarte, J., Furtunato Maia, J. M., Tóta, J., Dias, N., Fisch, G., Schumacher, C., Acevedo, O., Rezende Mercer, J., and Yañez-Serrano, A. M.: Linking Meteorology, Turbulence, and Air Chemistry in the Amazon Rain Forest, B. Am. Meteorol. Soc., 97, 2329-2342, https://doi.org/10.1175/BAMS-D-15-00152.1, 2016.

Göckede, M., Thomas, C., Markkanen, T., Mauder, M., Ruppert, J., and Foken, T.: Sensitivity of Lagrangian Stochastic footprints to turbulence statistics, Tellus B, 59, 577-586, https://doi.org/10.1111/j.1600-0889.2007.00275.x, 2007.

Goosse, H.: The energy balance, hydrological and carbon cycles, in: Climate System Dynamics and Modelling, chap. 2, Cambridge University Press, 2015.

Gotsch, S. G., Asbjornsen, H., Holwerda, F., Goldsmith, G. R., Weintraub, A. E., and Dawson, T. E.: Foggy days and dry nights determine crown-level water balance in a seasonal tropical montane cloud forest, Plant Cell Environ., 37, 261-272, https://doi.org/10.1111/pce.12151, 2014.

Herman, R. L., Ray, E. A., Rosenlof, K. H., Bedka, K. M., Schwartz, M. J., Read, W. G., Troy, R. F., Chin, K., Christensen, L. E., Fu, D., Stachnik, R. A., Bui, T. P., and Dean-Day, J. M.: Enhanced stratospheric water vapor over the summertime continental United States and the role of overshooting convection, Atmos. Chem. Phys., 17, 6113-6124, https://doi.org/10.5194/acp17-6113-2017, 2017.

Heusinkveld, V. W., Antoon van Hooft, J., Schilperoort, B., Baas, P., claire ten Veldhuis, M., and van de Wiel, B. J.: Towards a physics-based understanding of fruit frost protection using wind machines, Agr. Forest Meteorol., 282-283, 107868, https://doi.org/10.1016/j.agrformet.2019.107868, 2020.

Holmes, T. R. H., Owe, M., De Jeu, R. A. M., and Kooi, H.: Estimating the soil temperature profile from a single depth observation: A simple empirical heatflow solution, Water Resour. Res., 44, 1-11, https://doi.org/10.1029/2007WR005994, 2008.

Huffman, J. A., Prenni, A. J., DeMott, P. J., Pöhlker, C., Mason, R. H., Robinson, N. H., Fröhlich-Nowoisky, J., Tobo, Y., Després, V. R., Garcia, E., Gochis, D. J., Harris, E., MüllerGermann, I., Ruzene, C., Schmer, B., Sinha, B., Day, D. A., Andreae, M. O., Jimenez, J. L., Gallagher, M., Kreidenweis, S. M., 
Bertram, A. K., and Pöschl, U.: High concentrations of biological aerosol particles and ice nuclei during and after rain, Atmos. Chem. Phys., 13, 6151-6164, https://doi.org/10.5194/acp13-6151-2013, 2013.

Izett, J. G., Schilperoort, B., Coenders-Gerrits, M., Baas, P., Bosveld, F. C., and van de Wiel, B. J. H.: Missed Fog?, Bound.Lay. Meteorol., 173, 289-309, https://doi.org/10.1007/s10546019-00462-3, 2019.

Jacobs, A. F. G., Van Boxel, J. H., and El-Kilani, R. M. M.: Nighttime free convection characteristics within a plant canopy, Bound.-Lay. Meteorol., 71, 375-391, https://doi.org/10.1007/BF00712176, 1994.

Jiménez-Rodríguez, C. D., González-Angarita, A. P., CoendersGerrits, A., Savenije, H., and Wenninger, J.: Meteorological data and isotope signatures of water samples collected at La Selva, https://doi.org/10.4121/uuid:e70993d2-5852-4f639aff-39451fbd3fde, 2019a.

Jiménez-Rodríguez, C. D., González-Angarita, A. P., and CoendersGerrits, A. M. J.: Vapor Plumes Video at La Selva Biological Station. 4TU.Centre for Research Data, Dataset, 4TU.Centre for Research Data, https://doi.org/10.4121/uuid:997cc9d8-2281-453eb631-5f93cfebe00e, 2019b.

Jiménez-Rodríguez, C. D., Coenders-Gerrits, M., Wenninger, J., Gonzalez-Angarita, A., and Savenije, H.: Contribution of understory evaporation in a tropical wet forest during the dry season, Hydrol. Earth Syst. Sci., 24, 2179-2206, https://doi.org/10.5194/hess-24-2179-2020, 2020.

Jiménez-Rodríguez, C., Coenders, M., Schilperoort, B., GonzalezAngarita, A. P. (Adriana del Pilar): Visible vapor plumes in a tropical wet forest: R script, 4TU.ResearchData, Software, https://doi.org/10.4121/13720795, 2021.

Kao, C.-Y., Hang, Y.-H., Cooper, D., Eichinger, W., Smith, W., and Reisner, J.: High-resolution modeling of LIDAR data: Mechanisms governing surface water vapor variability during SALSA, Agr. Forest Meteorol., 105, 185-194, https://doi.org/10.1016/S0168-1923(00)00182-9, 2000.

Kelton, G. and Bricout, P.: wind velocity measurements using sonic techniques1, B. Am. Meteorol. Soc., 45, 571-580, https://doi.org/10.1175/1520-0477-45.9.571, 1964.

Kern, C., Masias, P., Apaza, F., Reath, K. A., and Platt, U.: Remote measurement of high preeruptive water vapor emissions at Sabancaya volcano by passive differential optical absorption spectroscopy, J. Geophys. Res.-Solid Ea., 122, 3540-3564, https://doi.org/10.1002/2017JB014020, 2017.

Klaassen, W., Bosveld, F., and de Water, E.: Water storage and evaporation as constituents of rainfall interception, J. Hydrol., 212-213, 36-50, https://doi.org/10.1016/S0022-1694(98)00200$5,1998$.

Knoche, H. R. and Kunstmann, H.: Tracking atmospheric water pathways by direct evaporation tagging: A case study for West Africa, J. Geophys. Res.-Atmos., 118, 12345-12358, https://doi.org/10.1002/2013JD019976, 2013.

Lankreijer, H., Lundberg, A., Grelle, A., Lindroth, A., and Seibert, J.: Evaporation and storage of intercepted rain analysed by comparing two models applied to a boreal forest, Agr. Forest Meteorol., 98-99, 595-604, https://doi.org/10.1016/S01681923(99)00126-4, 1999.

Lapidot, O., Ignat, T., Rud, R., Rog, I., Alchanatis, V., and Klein, T.: Use of thermal imaging to detect evaporative cooling in coniferous and broadleaved tree species of the Mediterranean maquis, Agr. Forest Meteorol., 271, 285-294, https://doi.org/10.1016/j.agrformet.2019.02.014, 2019.

Lavers, D. A., Ralph, F. M., Waliser, D. E., Gershunov, A., and Dettinger, M. D.: Climate change intensification of horizontal water vapor transport in CMIP5, Geophys. Res. Lett., 42, 5617-5625, https://doi.org/10.1002/2015GL064672, 2015.

Lawford, R.: Some scientific questions and issues for the GEWEX Continental-scale International Project (GCIP) research community, in: Proceedings of the Second International Science Conference on Global Energy and Water Cycle, 17-21 June, Washington, DC., pp. 162-167, 1996.

LI-COR: LI-7500RS, Open Path $\mathrm{CO}_{2} / \mathrm{H}_{2} \mathrm{O}$ Gas Analyzer, available at: https://www.licor.com/documents/c7tyf0czqn9ezkq1ki3b (last access: 29 June 2020), 2016.

Lieberman, D. and Lieberman, M.: Forest tree growth and dynamics at La Selva, Costa Rica (1969-1982), J. Trop. Ecol., 3, 347-358, https://doi.org/10.1017/S0266467400002327, 1987.

Loescher, H., Gholz, H., Jacobs, J., and Oberbauer, S.: Energy dynamics and modeled evapotranspiration from a wet tropical forest in Costa Rica, J. Hydrol., 315, 274-294, https://doi.org/10.1016/j.jhydrol.2005.03.040, 2005.

Loescher, H. W., Bentz, J. A., Oberbauer, S. F., Ghosh, T. K., Tompson, R. V., and Loyalka, S. K.: Characterization and dry deposition of carbonaceous aerosols in a wet tropical forest canopy, J. Geophys. Res.-Atmos., 109, D02309, https://doi.org/10.1029/2002JD003353, 2004.

Lundquist, J. D. and Huggett, B.: Evergreen trees as inexpensive radiation shields for temperature sensors, Water Resour. Res., 44, W00D04, https://doi.org/10.1029/2008WR006979, 2008.

Makarieva, A. M. and Gorshkov, V. G.: Biotic pump of atmospheric moisture as driver of the hydrological cycle on land, Hydrol. Earth Syst. Sci., 11, 1013-1033, https://doi.org/10.5194/hess-111013-2007, 2007.

Makarieva, A. M., Gorshkov, V. G., and Li, B.-L.: Revisiting forest impact on atmospheric water vapor transport and precipitation, Theor. Appl. Climatol., 111, 79-96, https://doi.org/10.1007/s00704-012-0643-9, 2013a.

Makarieva, A. M., Gorshkov, V. G., Sheil, D., Nobre, A. D., and Li, B.-L.: Where do winds come from? A new theory on how water vapor condensation influences atmospheric pressure and dynamics, Atmos. Chem. Phys., 13, 1039-1056, https://doi.org/10.5194/acp-13-1039-2013, 2013 b.

Mallick, K., Trebs, I., Boegh, E., Giustarini, L., Schlerf, M., Drewry, D. T., Hoffmann, L., von Randow, C., Kruijt, B., Araùjo, A., Saleska, S., Ehleringer, J. R., Domingues, T. F., Ometto, J. P. H. B., Nobre, A. D., de Moraes, O. L. L., Hayek, M., Munger, J. W., and Wofsy, S. C.: Canopy-scale biophysical controls of transpiration and evaporation in the Amazon Basin, Hydrol. Earth Syst Sci., 20, 4237-4264, https://doi.org/10.5194/hess-20-4237-2016, 2016.

Manoli, G., Domec, J.-C., Novick, K., Oishi, A. C., Noormets, A., Marani, M., and Katul, G.: Soil-plant-atmosphere conditions regulating convective cloud formation above southeastern US pine plantations, Glob. Change Biol., 22, 2238-2254, https://doi.org/10.1111/gcb.13221, 2016.

Mauder, M. and Zeeman, M. J.: Field intercomparison of prevailing sonic anemometers, Atmos. Meas. Tech., 11, 249-263, https://doi.org/10.5194/amt-11-249-2018, 2018. 
Moncrieff, J., Clement, R., Finnigan, J., and Meyers, T.: Averaging, Detrending, and Filtering of Eddy Covariance Time Series, 731, Springer Netherlands, Dordrecht, https://doi.org/10.1007/14020-2265-4_2, 2005.

Murakami, S.: A proposal for a new forest canopy interception mechanism: Splash droplet evaporation, J. Hydrol., 319, 72-82, https://doi.org/10.1016/j.jhydrol.2005.07.002, 2006.

Nakshabandi, G. A. and Kohnke, H.: Thermal conductivity and diffusivity of soils as related to moisture tension and other physical properties, Agric. Meteorol., 2, 271-279, https://doi.org/10.1016/0002-1571(65)90013-0, 1965.

Nieto, H., Kustas, W. P., Torres-Rúa, A., Alfieri, J. G., Gao, F., Anderson, M. C., White, W. A., Song, L., Alsina, M. d. M., Prueger, J. H., McKee, M., Elarab, M., and McKee, L. G.: Evaluation of TSEB turbulent fluxes using different methods for the retrieval of soil and canopy component temperatures from UAV thermal and multispectral imagery, Irrigation Science, 37, 389406, https://doi.org/10.1007/s00271-018-0585-9, 2019.

Peters, G., Fischer, B., and Kirtzel, H. J.: One-Year Operational Measurements with a Sonic AnemometerThermometer and a Doppler Sodar, J. Atmos. Ocean. Tech., 15, 18-28, https://doi.org/10.1175/15200426(1998)015<0018:OYOMWA>2.0.CO;2, 1998.

Pielke, R.: Mesoscale Meteorological Modeling, International Geophysics, Elsevier Science, available at: https://books.google.nl/ books?id=ExlFulltapcC (last access: 20 December 2019), 2013.

Pöschl, U., Martin, S. T., Sinha, B., Chen, Q., Gunthe, S. S., Huffman, J. A., Borrmann, S., Farmer, D. K., Garland, R. M., Helas, G., Jimenez, J. L., King, S. M., Manzi, A., Mikhailov, E., Pauliquevis, T., Petters, M. D., Prenni, A. J., Roldin, P., Rose, D., Schneider, J., Su, H., Zorn, S. R., Artaxo, P., and Andreae, M. O.: Rainforest Aerosols as Biogenic Nuclei of Clouds and Precipitation in the Amazon, Science, 329, 15131516, https://doi.org/10.1126/science.1191056, 2010.

R Core Team: R: A Language and Environment for Statistical Computing, R Foundation for Statistical Computing, Vienna, Austria, available at: https://www.R-project.org/ (last access: 20 December 2019), 2017.

Roberts, J.: Plants and water in forests and woodlands, in: EcoHydrology, 1st Edition, Taylor and Francis Group 181-236, Routledge, https://doi.org/10.4324/9780203980095, 1999.

Rodriguez-Gomez, C., Ramirez-Romero, C., Cordoba, F., Raga, G. B., Salinas, E., Martinez, L., Rosas, I., Quintana, E. T., Maldonado, L. A., Rosas, D., Amador, T., Alvarez, H., and Ladino, L. A.: Characterization of culturable airborne microorganisms in the Yucatan Peninsula, Atmos. Environ., 223, 117183, https://doi.org/10.1016/j.atmosenv.2019.117183, 2020.

Rosa, I. M., Smith, M. J., Wearn, O. R., Purves, D., and Ewers, R. M.: The Environmental Legacy of Modern Tropical Deforestation, Curr. Biol., 26, 2161-2166, https://doi.org/10.1016/j.cub.2016.06.013, 2016.

Sanford Jr., R. L., Paaby, P., Luvall, J. C., and Phillips, E.: Climate, geomorphology, and aquatic systems., in: La Selva. Ecology and natural history of a Neotropical Rainforest, edited by: McDade, L. A., Bawa, K. S., Hespenheide, H. A., and Hartshorn, G. S., chap. 3, 19-33, The University of Chicago Press, 1994.

Savenije, H. H. G.: The importance of interception and why we should delete the term evapotranspiration from our vocabulary, Hydrol. Process., 18, 1507-1511, https://doi.org/10.1002/hyp.5563, 2004.

Saxton, K. and Rawls, W.: Soil Water Characteristic Estimates by Texture and Organic Matter for Hydrologic Solutions, Soil Sci. Soc. Am. J., 70, 1569-1578, https://doi.org/10.2136/sssaj2005.0117, 2006.

Schellekens, J., Bruijnzeel, L. A., Scatena, F. N., Bink, N. J., and Holwerda, F.: Evaporation from a tropical rain forest, Luquillo Experimental Forest, eastern Puerto Rico, Water Resour. Res., 36, 2183-2196, https://doi.org/10.1029/2000WR900074, 2000.

Schilperoort, B., Coenders-Gerrits, M., Luxemburg, W., Jiménez Rodríguez, C., Cisneros Vaca, C., and Savenije, H.: Technical note: Using distributed temperature sensing for Bowen ratio evaporation measurements, Hydrol. Earth Syst. Sci., 22, 819830, https://doi.org/10.5194/hess-22-819-2018, 2018.

Shuttleworth, W.: Evaporation, in: Handbook of hydrology, edited by: Maidment, D. R., chap. 4, 4.1-4.53, Mc-Graw Hill, Inc., New York, 1993.

Sioris, C. E., Malo, A., McLinden, C. A., and D'Amours, R.: Direct injection of water vapor into the stratosphere by volcanic eruptions, Geophys. Res. Lett., 43, 7694-7700, https://doi.org/10.1002/2016GL069918, 2016.

Sollins, P., Sancho M., F., Mata Ch., R., and Sanford Jr., R. L.: Soils and soil process research, in: La Selva. Ecology and natural history of a Neotropical Rainforest, edited by: McDade, L. A., Bawa, K. S., Hespenheide, H. A., and Hartshorn, G. S., chap. 4, 34-53, The University of Chicago Press, 1994.

Sparks, W. B., Richter, M., deWitt, C., Montiel, E., Russo, N. D., Grunsfeld, J. M., McGrath, M. A., Weaver, H., Hand, K. P., Bergeron, E., and Reach, W.: A Search for Water Vapor Plumes on Europa using SOFIA, Astrophys. J., 871, L5, https://doi.org/10.3847/2041-8213/aafb0a, 2019.

Spellman, F. R.: The Handbook of Meteorology, Scarecrow Press, available at: http://ebookcentral.proquest.com/lib/delft/ detail.action?docID=1077405 (last access: 20 December 2019), 2012.

Strong, M., Sharp, Z. D., and Gutzler, D. S.: Diagnosing moisture transport using D/H ratios of water vapor, Geophys. Res. Lett., 34, L03404, https://doi.org/10.1029/2006GL028307, 2007.

Stull, R. B.: An introduction to boundary layer meteorology, vol. 4, Springer Netherlands, Dordrecht, 1 edn., https://doi.org/10.1007/978-94-009-3027-8, 1988.

Stull, R. B.: Practical meteorology: an algebra based survey of atmospheric science, BC Campus, available at: http://www.eos. ubc.ca/books/Practical_Meteorology/ (last access: 20 December 2019), 2017.

Tang, H., Dubayah, R., Swatantran, A., Hofton, M., Sheldon, S., Clark, D. B., and Blair, B.: Retrieval of vertical LAI profiles over tropical rain forests using waveform lidar at La Selva, Costa Rica, Remote Sens. Environ., 124, 242-250, https://doi.org/10.1016/j.rse.2012.05.005, 2012.

Terando, A. J., Youngsteadt, E., Meineke, E. K., and Prado, S. G.: Ad hoc instrumentation methods in ecological studies produce highly biased temperature measurements, Ecol. Evol., 7, 98909904, https://doi.org/10.1002/ece3.3499, 2017.

Thompson, A.: Simulating the adiabatic ascent of atmospheric air parcels using the cloud chamber, Department of Meteorology, Penn State, 2007. 
Trzeciak, T. M., Garcia-Carreras, L., and Marsham, J. H.: CrossSaharan transport of water vapor via recycled cold pool outflows from moist convection, Geophys. Res. Lett., 44, 15541563, https://doi.org/10.1002/2016GL072108, 2017.

Valsan, A. E., Priyamvada, H., Ravikrishna, R., Després, V. R., Biju, C., Sahu, L. K., Kumar, A., Verma, R., Philip, L., and Gunthe, S. S.: Morphological characteristics of bioaerosols from contrasting locations in southern tropical India - A case study, Atmos. Environ., 122, 321-331, https://doi.org/10.1016/j.atmosenv.2015.09.071, 2015.

van der Ent, R. J. and Savenije, H. H. G.: Length and time scales of atmospheric moisture recycling, Atmos. Chem. Phys., 11, 18531863, https://doi.org/10.5194/acp-11-1853-2011, 2011.

Wang, J., Krejci, R., Giangrande, S., Kuang, C., Barbosa, H. M. J., Brito, J., Carbone, S., Chi, X., Comstock, J., Ditas, F., Lavric, J., Manninen, H. E., Mei, F., Moran-Zuloaga, D., Pöhlker, C., Pöhlker, M. L., Saturno, J., Schmid, B., Souza, R. A. F., Springston, S. R., Tomlinson, J. M., Toto, T., Walter, D., Wimmer, D., Smith, J. N., Kulmala, M., Machado, L. A. T., Artaxo, P., Andreae, M. O., Petäjä, T., and Martin, S. T.: Amazon boundary layer aerosol concentration sustained by vertical transport during rainfall, Nature, 539, 416-419, https://doi.org/10.1038/nature19819, 2016.
Wang, P. K.: Moisture plumes above thunderstorm anvils and their contributions to cross-tropopause transport of water vapor in midlatitudes, J. Geophys. Res.-Atmos., 108, 4194, https://doi.org/10.1029/2002JD002581, 2003.

Wright, J. S., Fu, R., Worden, J. R., Chakraborty, S., Clinton, N. E., Risi, C., Sun, Y., and Yin, L.: Rainforest-initiated wet season onset over the southern Amazon, P. Natl. Acad. Sci., 114, 84818486, https://doi.org/10.1073/pnas.1621516114, 2017.

Zhang, R., Huang, J., Wang, X., Zhang, J. A., and Huang, F.: Effects of precipitation on sonic anemometer measurements of turbulent fluxes in the atmospheric surface layer, Journal of Ocean University of China, 15, 389-398, https://doi.org/10.1007/s11802-0162804-4, 2016. 